\title{
Diyabetli Bireylerde Tıbbi Beslenme Tedavisine Uyum Sorunları
}

\author{
Adherence Problems in Medical Nutrition Therapy of People with Diabetes
}

\author{
Hülya Gökmen Özel ${ }^{1}$
}

Geliş tarihi/Received: 07.03.2019 • Kabul tarihi/Accepted: 12.05.2019

\section{ÖZET}

Tıbbi beslenme tedavisine uyum çoğu hastanın uyumluluk, kısmen uyumluluk ve uyumsuzluk arasında yer değiştirdiği dinamik bir süreçtir. Sağlık çalışanları çoğu zaman uyum sözcüğünü kullansalar da, doğru terminoloji hakkında çeşitli tartışmalar mevcuttur. Beslenme tedavisine uyumu tanımlamada üç terim kullanılmaktadır. Beslenme tedavisine uyum (compliance) diyetisyenlerin önerilerine hasta davranışlarının ne ölçüde uyduğudur. Diyetisyenlerin talimatlarına riayet etme veya itaat anlamına gelir. Bu terim içerisinde negatif anlamı barındırmaktadır. Zorlama ve utancı kapsar. Beslenme tedavisine bağlı kalma (adherence), diyeisyenlerin hasta veya ailesi tarafından kabul edilmiş önerilerine hasta davranışlarının ne ölçüde uyduğudur. Beslenme tedavisine bağlllık ve sadakati içerir. Yargısal olmayandır. Beslenme tedavisinde ahenkli çalışma ise (concordance) hastanın inançlarına ve alışkanlıklarına saygı gösterecek şekilde, hasta ve diyetisyen arasındaki uzlaşmadan sonra ulaşılan anlaşma olarak tanımlanmıştır. Diyabette beslenme tedavisine uyumu ölçen tek parametre bulunmamaktadır. Diyabetle yaşayan bireylerin öneri ve tedavilerine ölçümü gösteren tanımlamalara gerek vardır. Beslenme tedavisine uyum konusunda hastalar desteklenmeli suçlanmamalı, sağlık çalışanları da uyumu arttırma konusunda eğitilmelidir.

Anahtar kelimeler: Diyabet, trbbi beslenme tedavisi, uyum

\begin{abstract}
Compliance to medical nutrition therapy is a dynamic process, with many patients changing between a state of compliance and partial and noncompliance. Although clinicians often use the word compliance, there is much debate about the correct terminology. There are three terms used to define the compliance to nutrition therapy; compliance suggests conformity or a type of obedience in following dietitian's orders, whereas adherence suggests support, devotion, or allegiance. Compliance carries negative connotations; it suggests an element of compulsion and blame, whereas adherence is nonjudgmental. Adherence to nutrition therapy describes the extent to which the patient's behavior matches agreed recommendations from the dietitian. It includes commitment, loyalty to nutrition therapy. Adherence is nonjudgmental. Concordance refers an agreement reached after negotiation between a patient and a dietitian that respects the beliefs and wishes of the patient. No single measure will determine all faces of conformity with treatment in people with diabetes. There is a need for clear definitions and measurements of adherence to treatment and advice in living with diabetes. Patients need to be supported, not blamed, and health professionals need to be trained in terms of adherence to nutrition therapy.
\end{abstract}

Keywords: Diabetes, medical nutrition therapy, adherence, compliance, concordance

1. İletişim/Correspondence: Hacettepe Üniversitesi Sağlık Bilimleri Fakültesi

Beslenme ve Diyetetik Bölümü, Ankara, Türkiye

E-posta: hgokmen@hacettepe.edu.tr • 『 https://orcid.org/0000-0002-8282-6468 


\section{GİRIŞ}

Beslenme ve diyet tedavisi yaşam döngüsünün her aşamasında her türlü hastalığı kapsamaktadır. Son ylllarda kronik hastalıkların daha yaygin olarak ortaya çıkması ve hastaların tedavide daha etkin rol almalarından dolayı, tedaviye uyum daha fazla önem kazanmıştır (1). Dünya Sağlık Örgütü (Word Health Organisation [WHO]) 2003 yllında kronik hastalıklarda tedaviye uyumla ilgili yayınladığı raporda, gelişmiş ülkelerde kronik hastalığı olan hastaların sadece $\% 50$ 'sinin tedavi önerilerine uyduğunu, gelişmekte olan ülkelerde bu oranın daha düşük olduğunu belirtmiştir (2). Dimatteo (1) tarafından yapılan 19481998 yılları arasında 50 yıllık bir sürede tedaviye uyumun değerlendirildiği 569 çalışmanın meta analizi sonucunda, 17 hastalık arasinda tedaviye uyumsuzluk ortalama oranının \%24.8 olduğu ve bu 17 hastalık arasinda en sık tedaviye uyumsuzluk gösteren hastalığın diyabet (tedaviye uyumsuzluk oranı \%32.5) olduğu bulunmuştur (1).

Beslenme tedavisine uyum sorunları beslenme tedavisi uygulanması gereken tüm hastalıklarda ve tüm yaş gruplarında yaygın görülmektedir ve tedaviye uyum özellikle yaş arttıkça (özellikle 10 yaşından sonra) bozulmaktadır (3,4). Kalıtsal metabolizma hastalıkları, tip 1 diyabet, çölyak ve kistik fibrozis gibi özel beslenme tedavisi gerektiren pediatrik hasta grubu, sağlıklı çocuklara göre davranışsal ve duygusal sorunlar açısından iki kat daha fazla risk altındadır. Bu gibi kronik hastalıklar ailenin yaşam tarzını, tatil veya hafta sonu geç kalkma gibi normal aktiviteleri uygulamasını etkilemektedir (3).

Hastaların beslenme tedavisine uyumları, sağlık çalışanları için uzun yıllardır endişe kaynağı olmayı sürdürmektedir. $\mathrm{Bu}$ derleme makalede diyabet tedavisinin önemli bir parçası olan tıbbi beslenme tedavisine uyum sorunları, uyumun ölçülmesinde kullanılan parametreler ve uyumu arttırmak için uygulanacak stratejiler üzerinde durulacaktır.

\section{Tedaviye Uyumun Tarihçesi}

Tedaviye uyumsuzluklailgiliilkbilgiHipokrat(MÖ460370) döneminden gelmektedir. Hipokrat hastaların “ilaçlarını alır gibi göründüğünden” bahsetmiştir. Bir grup fizyolog 1950 yılında tüberkülostatik ajanlar ile yaptıkları bir poliklinik çalışmasında uyumsuzluk olgusuna dikkat çekmişlerdir. Bugünkü anlamıyla tedaviye uyumsuzluk ilk kez David Sackett tarafindan 1972 yılında ortaya konmuş ve hipertansiyon hastalığı tedavisi esnasında gerçekleşen öngörülemeyen veya moral bozucu yanıtın, tedaviye uyumun düşük olmasından kaynaklandığı gösterilmiştir. 1961-1974 ylları arasinda tedaviye uyumsuzlukla ilgili sadece 245 makale yayınlanmıştır (5). İlk kez 1974 yılında tedavi rejimlerine uyumla ilgili McMaster Çalıştayı/ Sempozyumu gerçekleştirilmiş ve sonucunda "Uyum ve Uyum Araştırmaları" adında bir kitap yayınlanmıştır. Bu sempozyum sonrası 1970’lerin sonlarında tedaviye uyumun bileşenlerinin karmaşı olduğu ve iyi anlaşılmadığı ortaya konmuştur. 1980’li yllardan itibaren de tedaviye uyum alanında birçok çalışma devam etse de, çok az gelişme veya yeni yaklaşım ortaya konabilmiştir (5).

\section{Tıbbi Beslenme Tedavisine Uyumla İlişkili Tanimlar}

Beslenme tedavisine uyum çoğu hastanın uyumluluk, kısmen uyumluluk ve uyumsuzluk arasında yer değiştirdiği dinamik bir süreçtir. Sağlık çalışanları çoğu zaman uyum sözcüğünü kullansalar da, doğru terminoloji hakkında çeşitli tartışmalar mevcuttur. Tedaviye uyumu tanımlamada üç terim kullanılmaktadır. Bu terimler, beslenme tedavisine uyumu tanımlamada da kullanılabilir. Beslenme tedavisine uyum (compliance) diyetisyenlerin önerilerine hasta davranışlarının ne ölçüde uyduğudur. Diyetisyenlerin talimatlarına riayet etme veya itaat anlamına gelir. Bu terim içerisinde negatif anlamı barındırmaktadır. Zorlama ve utancı kapsar. Beslenme tedavisine bağlı kalma (adherence), diyetisyenlerin hasta veya ailesi tarafindan kabul 
edilmiş önerilerine hasta davranışlarının ne ölçüde uyduğudur. Beslenme tedavisine bağlılık, sadakat ve tabiyeti içerir. Pozitif anlamı barındırdığı için son ylllarda uyum (compliance) yerine kullanılmaktadır. Yargısal olmayandır. Diyetisyen-hasta ilişkisinde uyumun barındırdığı sağlık çalışanı baskınlığını azaltır. Büyük Britanya Farmosötik Birliği tedaviye uyum ile ilgili eski yaklaşımların yetersiz kaldığı düşüncesi ile terminolojiyi anlaşma ve uygunluğu da içeren ahenke (concordance) dönüştürmeye karar vermiştir. Tedaviye karşı hastalar tarafından gösterilen direnç sanıldığından daha derin ve daha yaygındır. Ayrıca uyum içerisinde hastanın moral ve psikolojik durumunda sıkintı vardır. Beslenme tedavisinde ahenkli çalışma (concordance) hastanın inançlarına ve alışkanlıklarına saygı gösterecek şekilde, hasta ve diyetisyen arasındaki uzlaşmadan sonra ulaşılan anlaşma olarak tanımlanmıştır. Paylaşımcıdır, interaktiftir. Tedavi hedefleri ve stratejileri hakkında karar verici davranışları içerir. Hasta ve diyetisyen ortaklığını barındırır ve diyetisyenin hasta ve ailesinin kararlarına öncelik verdiği bir anlaşmadır. Ahenk modelinin omurgasını hasta ve ailesi oluşturmaktadır. Hasta ve ailesi karar verici pozisyondadır. Diyetisyen empati yapar. Uyum kelimesi tedaviye teorik yaklaşımı, ahenkli çalışma ise tedavinin pratik ve etik boyutlarını da içermektedir $(5,6)$. Hasta ve ailesi ile sağlık çalışanının birlikte çalışması arzu edilendir. Ancak bazı hasta ve aileleri sağlık çalışanının düşüncesini uygulamayı daha doğru bulurlar veya tercih edebilirler (6).

\section{Tıbbi Beslenme Tedavisine Uyum Neden Zayıftır?}

Beslenme tedavisine uyum kognitif, duygusal, fizyolojik ve kültürel etmenlerden etkilenmektedir. Tedavide dört farklı tür uyumsuzluk tanımlanmıştır: (i) Risk altındaki popülasyon: Acil yardıma ulaşmada gecikme, (ii), Tarama: İlişkili sağlık programlarına katılmama, (iii) İzlem: Randevulara gelmeme ve (iv) Tedavi: Sağlık çalışanının önerilerine uymama. $\mathrm{Bu}$ basamaklar tıbbi tedaviye uyumsuzluk için tanımlansa da beslenme tedavisine uyumsuzluğu göstermek için de kullanılabilir. Tıbbi tedavide en sık karşılaşılan uyum sorunları eczaneden ilacın alınmaması, ilacın doğru dozunun kullanılmaması, ilacın yanlış zamanlarda alınması, ilacın bazı dozlarının alınmasının unutulması ve özellikle akut hastalıklar için tedaviye erken dönemde son verilmesidir (5).

Kronik bir hastanın başa çıkması gereken üç önemli unsur vardır: (i) Hastalığın kendisi (semptomları, tanı, tedavi vb.), (ii) Günlük yaşam ve (iii) Biyografi (kişiliğinin/kimliğinin yeniden inşa edilmesi) (5). Diyabetli bireylerde beslenme tedavisine uyumun kötü olması ile ilişkili olabilecek etmenler Tablo 1'de görülmektedir (6).

\section{Tedavide Standart, Tutarlı ve Uyumlu Bilginin Kullanılmaması: Diyabet tedavisi ile ilgili oluşturulmuş ulusal veya uluslararası tedavi rehberleri olsa da, bazen aynı sağlık ekibinin üyeleri hasta ve ailelerine farklı önerilerde bulunabilirler}

Tablo 1. Diyabetli hastalarda beslenme tedavisine zayıf uyumla ilişkili etmenler (6)

\section{Bariyerler}

- Tedaviye ulaşımın olmaması

- Sosyal işleyişlerin zayıf olması

- Tıbbi sistemin uygulanması ile ilgili zorluklar

- Hastanın yaşam koşulları (ayrı ebeveynler gibi)

- Beslenme tedavisi ile ilgili bilginin eksik olması

- Hastalık veya beslenme tedavisine karşı olumsuz tutum, hastalığın reddedilmesi, kötü uyumun olumsuz sonuçlar doğuracağı konusundaki inanç eksikliği

- Hasta veya bakımdan sorumlu kişinin bilgi düzeyinin veya • kognitif işlevlerinin düşük olması

- Tedavinin tüm yönlerini yönetebilmek için zaman eksikliği

- Sosyal ve aile desteğinin az olması

- Motivasyon yokluğu ve ilgisizlik

- Eğitim durumunun düşük olması

- Adölesan dönemi

- Kişinin diyabetli olarak damgalanması

- Aile kültürü, geniş aileler

- Hastalık ve tedavisi konusunda çelişkili yaklaşımların olması, hastalığa ilişkin ailenin inançları, yeni geçerli tedavi yöntemlerine karşı direnç olması

Beslenme tedavisine uyum olmadığında semptom görülmemesi

Diyetisyen, hasta ve aile ilişkisinin kötü olması

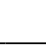


veya hasta, alanında uzman bir ekip tarafindan izlenmiyor olabilir. Bazen diyabet konusunda deneyimi ve yeterince bilgisi olmayan birinci basamak sağlık çalışanları da hasta ve ailelerine çelişkili bilgiler verebilmektedir. Diyabette tedavi hedefleri iyi tanımlanmıştır, etkili tedavi yöntemleri bulunmaktadır ve pratik öneriler açıtır. Diyabette tedaviye uyumsuzluğun temel nedenlerinden birisi klinik eylemsizlik (klinik atalet) olabilir (7).

Atalet kelime anlamı olarak tembellik, işsizlik anlamina gelmektedir. Sosyal bilimlerde atalet eylem yeteneğinde zayıflık, harekete geçmeme, yılgınlık, yavaşlık ve tükenmişlik anlamına gelirken, yönetim bilimlerine ise kurumun çevresindeki gelişmelere tepki verme hızının düşük olması, yapısının hantal olması ve kurumsal işlevlerini yerine getirmedeki yavaşlığıdır. Atalet ayrıca bireysel, entellektüel ve toplumsal olarak da tanımlanmıştır. Amaca yönelik olarak eyleme geçememe, bireylerde görülen yavaşlık, isteksizlik, uyuşukluk ve miskinlik hali olarak tanımlanan durum bireysel atalettir. Bireyde ortaya çıkma düzeyine göre fiziksel ve zihinsel atalet olmak üzere iki farklı şekilde görülebilir. Fiziksel atalet, bireyin maddi ve fiziksel varlığında meydana gelen atalet olarak tanımlanırken, zihinsel atalet, bireyin soyut ve psikolojik bir yapıya sahip olan zihninde meydana gelen atalettir. Bireyin yeni bir şeyler öğrenmek için çaba göstermemesi, karşılaştığı yeni sorunların çözümünde hiçbir revizyon ve güncelleme yapmadan geçmiş bilgi ve deneyimlerine sıkı sıkıya bağlı kalması entellektüel atalet olarak adlandırllırken, toplumsal atalet toplumların eylem yeteneğindeki zayıflık ve harekete geçememe durumudur (8).

Klinik atalet potansiyel olarak etkinliği kanıtlanmış tedavinin sağlık çalışanı tarafından az kullanılması veya tercih edilmemesidir. Kronik hastalıklarda hastaların yetersiz bakıma maruz kalmalarına katkıda bulunan temel etmendir ve asemptomatik kronik hastalıklarda daha önemli bir sorundur (7). Klinik ataletin \%50'si sağlık çalışanından kaynaklı etmenlerdir (tedaviyi başlatamama, hedefleri yakalamak amacıyla tedaviyi iyi yönetememe, depresyon gibi komorbid durumların tanısı ve yönetilmesinde zorluk, hastaya ayrllan zamanın yetersiz olması ve ileriyi düşünen bakımdan ziyade tepkisel bakımın verilmesi gibi). Yüzde 30'u ise hasta ile ilişkili etmenlerden (hastalığın inkar edilmesi, hastalığın ciddi olmadığına inanılması, sağlık okuryazarlığının düşük olması, birden fazla ilaç kullanma zorunluluğu, ilaçların maliyeti ve sosyal kurumlarca tümünün karşılanmaması, ilaçların yan etkisinin bulunması, sağlık çalışanı-hasta iletişiminin zayıf olması, sağlık çalışanına güvenmeme, depresyon ve madde kullanımı gibi etmenlerin varlığı) ve \%20'si de sistemleilişkili(hastalıkla klinikrehberlerin olmaması, muayene için randevu sisteminin olmaması, sosyal hizmetlerin zayıf olması, ekip yaklaşımının olmaması ve sağlık çalışanı ve personel arasındaki iletişimin zayıf olması) etmenlerden kaynaklanmaktadır (9).

Kontrolsüz Bilgi: Diyabetli çocuğa sahip aileler web sitelerinde, çeşitli sosyal medya ortamlarında aşırı miktarda sınırsız ve kontrol edilmemiş bilgi ile karşılaşmaktadır. Ulusal veya uluslararası hasta organizasyonları da hastalık ve tedavisi hakkında bilgi vermektedir. Ailelerin dil sorunlarının olması, farklı ülkelerdeki farklı uygulamalar uluslararası hasta organizasyonlarının hastalık ve tedavisi hakkında verdiği bilgilerin aileler tarafindan yorumlanmasını zorlaştırmaktadır (3).

Eşlik Eden Hastalıklar/Depresyon: Diyabete eşlik eden diğer hastalıklar (depresyon, hipertansiyon, koroner arter hastalı̆̆ı, hiperlipidemi, çölyak, alkolizm gibi), diyabette tıbbi beslenme tedavisine uyumun zayıf olmasında en önemli etmenlerden birisidir. Türkiye'de tip 2 diyabetli 110 hastada yaplan bir çalışmada, orta ve ciddi derecede depresyon oranı \%30.9 olarak bulunmuş ve hastalık süresi arttıkça depresyon skorunun arttığı gösterilmiştir (10). Özellikle çocuk hastaların öğün seçiminde bağımsız olmamaları, hastalığın beslenme tedavisi konusundaki çaresizlik ve utanç duygusu beslenme tedavisine uyumu etkileyen diğer önemli etmenlerden birisidir. Tibbi beslenme tedavisinin önemli bir tedavi bileşeni olduğu farklı hasta gruplarında yapılan çalışmalarda, hastaların \%30'unun ve ebeveynlerinin ise \%22'sinin 
hastalığın beslenme tedavisi konusunda kendilerini çaresiz hissettikleri gösterilmiştir. Yine aynı hasta grubunda hastalarm \%29.5'inin ve ebeveynlerin \%35’inin tüm besinlerin rahatça tüketilmediği utanç duygusuna sahip olduğu bulunmuştur (11).

Bilişsel İşlevlerin Sınırlı Olması: Diyabette kognitif disfonksiyon gelişimine neden olan etmenlerden bazıları, kronik hiperglisemi, akut veya tekrarlayan hipoglisemiler, diyabetli olma süresi, hipertansiyon, hiperkolesterolemi, dislipidemi, obezite, mikro ve makrovasküler komplikasyonların varlığı, endotel disfonksiyon, kan-beyin bariyeri geçirgenliğindeki değişiklikler ile nöroinflamatuvar beyin hastalıklarına genetik yatkınlıktır. Tip 1 diyabetli hastalarda etkilenen işlevler, zeka, dikkat, psikomotor hız, bilişsel esneklik ve görsel algılama iken, tip 2 diyabette öğrenme ve hafıza daha çok etkilenmektedir. Tip 1 diyabetli hastalardaki kognitif azalma daha yavaş ilerlemektedir ve hafif düzeydedir ve yaşam boyu HbA1c düzeyleri ile kognitif işlevlerdeki azalma arasında korelasyon bulunmaktadır (12). Hastaların bilişsel işlevlerinin sınırlı olması, tedavinin etkin bir şekilde uygulanmasını zorlaştırmaktadır. Yapılan bir çalışmada hastaların \%56'sının klinikten hemen ayrıldıktan sonra tedavi ile ilgili önerileri hatırlamadıkları gösterilmiştir. Tedaviye ilişkin fazla bilgi verildiğinde, hasta ve sağlık çalışanı arasındaki sözel iletişimde “Tıbbi Jargon” kullanıldığında, tedaviye ilişkin detaylı bilgi verilmediğinde, hasta/ ailesinin tedaviye ilişkin soru sormasına izin verilmediğinde, tedavi önerilerinin hatırlanmadığı ve bu hastalarda beslenme tedavisine uyumsuzluğun daha fazla olduğu gösterilmiştir (13).

Sağlık Okur Yazarlığının Sınırlı Olması: Sağlık okuryazarlığı için Tıp Enstitüsü’nün tanımı, bireylerin sağlıkla ilgili doğru karar verebilmek için gerekli temel sağlık bilgilerini ve bakımlarını anlama kapasiteleri şeklindedir. Sağlık okur-yazarlığının yetersizliğini gösteren ilk çalışma 1995 yllında yayınlanmıştır. $\mathrm{Bu}$ çalışmada akut tedavi alması gereken hastaların büyük bir kısmının ilaç kullanım talimatı ve bir sonraki randevu zamanı gibi temel tıbbi talimatları okuma ve anlamada zorluk çektiği bulunmuştur (14).
Geniş bir hasta popülasyonunda (2659 hasta) yapılan diğer bir çalışmada, hastaların yaklaşık 1/3'inin sağlık okur-yazarlığının yetersiz olduğu, \%42'sinin ilaçları alım talimatlarını anlamadı̆̆ı, \%25'inin sonraki muayene randevusunu hatırlamadıkları, \%60'sının hastalıkla ilişkili dokümanı anlamada ve okumada yetersiz kaldığı bulunmuştur. Talimatları anlamada yaşlı hastaların ve dil sorunları olan hastaların daha fazla zorluk çektiği gösterilmiştir (5).

Diyabette sağlık okur-yazarlığı ise kendi kendine izlem ve numerik hesaplamaları yapma ve anlama becerilerini kapsamaktadır. Amerikalı yetişkinlerin \%36’sının temel sağlık bilgilerini anlamak için gerekli okur-yazarlılığının sınırlı olduğu bilinmektedir. $\mathrm{Bu}$ nedenle diyabetli bazı bireylerin doğru insülin dozunu yapamadıkları, besin etiketlerini okuduklarında anlamadıkları veya porsiyon büyüklüklerini yanlış tahmin ettikleri bilinmektedir. Diyabette sağlık okuryazarlığının düşük olması, hipoglisemi sıklığının, son dönem böbrek yetmezliği mortalitesinin ve HbA1c düzeyinin artması ile ilişkili bulunmuştur (14). Amerika'da yapılan bir çalışmada diyabetli bireylerin \%56'sinın 1 paket cipsin karbonhidrat miktarını, \%59'unun ise karbonhidrat ve kan glukoz düzeylerine göre insülin dozunu hesaplayamadıkları gösterilmiştir (14). Sağlık okur-yazarlığını ölçmek için çeşitli ölçekler kullanılmaktadır. $\mathrm{Bu}$ ölçekler temel olarak yazılı materyalden okuyabilme, düz yazının anlaşılması ve sayısal hesaplamaları yapabilme becerilerini kapsamaktadır. Bazı ölçekler sağlık okur-yazarlığını ölçerken, bazı ölçekler genel tıbbi terimlerin anlaşılırlığını test etmektedir, bazı ölçekler ise diyabete özgü geliştirilmiştir. Bu nedenle sağlık çalışanları, hastalarının sağlık okuryazarlığını mutlaka değerlendirmeli, sınırlı beceri ve yeteneği olan hastaları izlerken daha dikkatli davranmalı ve bu hastalarla iletişim kurma teknikleri konusunda eğitim almış olmalıdır (14).

Aile ile İlişkili Etmenler: Ailenin yaşam koşulları beslenme tedavisine uyumu etkileyen diğer bir etmendir. Ebeveynler çocuklarının bakım becerileri konusunda ve bu becerileri çocuklarına aktarma konusunda farklı kabiliyetlere sahiptir. Ebeveynler 
tedavide aktif rol aldıklarında, çocukları ile etkileşime geçtiklerinde ve duygusal destek sağladıklarında, çocuklar hastalıklarında yaşadıkları stresli olaylar karşısında daha aktif rol almaya hazır olurlar. Özellikle boşanan ailelerin çocuklarında, çocuğun yaşadığı üzüntü, çocuğun beslenme tedavisine uyumunu bozabilir. Ebeveyn desteği yokluğunda beslenme tedavisine uyma arzusu da azalır. Tek ebeveynli ailelerin sayısının artması ile bu hastaların özel desteğe gereksinmesi olduğu unutulmamalıdır $(15,16)$. Ailede birden fazla hasta çocuğun olması, ebeveynlerin işsiz olması, ebeveynlerin eğitim durumları da beslenme tedavisine uyumun bozulmasina neden olmaktadır (17). Ebeveynlerin hastalık ve tedavisi ile ilgili sorumluluklarının fazla olmasindan dolayı, ebeveynlerde anksiyete ve depresyon daha fazla görülmektedir. Annede depresif semptomların olması, çocuğun metabolik kontrolünü ve beslenme tedavisine uyumunu bozmaktadır. Çocuğun yaşı küçüldükçe ebeveynlerdeki anksiyete ve depresyon artmaktadır (18).

Adölesan ve Erişkin Dönem: Amerika'da 13-17 yaşları arasında 4914 tip 1 diyabetli adolesanın HbA1c düzeylerinin değerlendirildiği bir veri tabanına göre, HbA1c düzeyi $<\% 7.5$ olan hasta oranı $\% 17,<\% 7$ olan hasta oranı \%6 bulunmuştur ve hastaların ortalama HbA1c düzeyleri \%9'dur (19). Adölesanlarda ebeveynhasta çatışması, akran baskısı, arkadaşları ile vakit geçirme istekleri nedeniyle tedaviye yeterince zaman ayıramamaları ve motivasyon eksikliği hastaların beslenme tedavisine uyumunu zayıflatmaktadır. Adölesan döneme geçiş evresinde, çocukların daha dazla bağımsızlık istekleri sonucunda ebeveynler çocuklarının tedavileri konusunda daha az sorumluluk almaktadır. Farklı hissetme, sosyal durumları yönetmede zorluklar, hastalığın karmaşık olması ve akranlarına açıklamada yaşanılan zorluklar, hastalıkları ile ilgili soruları yanıtlama isteksizlikleri, diyabetli adölesanların hastalıklarını reddetmesine ve tedaviyi aksatmalarına neden olabilmektedir $(6,20)$.

Beslenme Tedavisi ile İlişkili Etmenler: Diyabetli bireylerde beslenme tedavisine uyumu etkileyen beslenme ile ilişkili etmenlerden bazıları, düzenli olarak besin tüketimi, kan glukoz, ilaç/insülin saatleri/dozları ve egzersiz kaydı tutma zorunluluğu, besinlerin karbonhidrat içeriklerini tahmin etmede ve tartı kullanmada bazı zorlukların yaşanması, dışarıda yemek yeme, özel günler (doğum günü vb.), okulda/kreşte yemek yeme, etiket okuma, öğün saatlerine uyma, hipoglisemi için besin taşıma zorunluluğunun olması ve ayrıca ilaç/insülin saatleri ile besin tüketimi ilişkisinin kurulması konusundaki güçlüklerdir. Beslenme tedavisinde tartma/hesaplama gereği olmaksızın istendiği zaman tüketilebilecek besinlerin olması önemlidir ve ev dışında yemek yenilen yerlerde her zaman uygun/sağlıklı besinlere ulaşılamamaktadır. Besin ve öğünlerin paylaşılması günlük ve sosyal yaşamda önemlidir. Ailenin diğer üyeleritarafından hesapyapmadan serbestçe tüketilen besinler, diyabetli bireyler için uygun olmayabilir ve bu nedenle aileler çocuklarının aile üyeleri ile sofraya oturmasina izin vermeyebilir. Böylece öğün esnasında çocuk ve aile iletişimi kaybolmuş olacaktır. Kreş veya okula başladıktan sonra, çocukların beslenme tedavisi ile ilgili sorunlarında artış olmaktadır. Okul veya kreşteki diğer sağlıklı çocuklar diyabetli arkadaşlarına karşı acımasız olabilmektedir. Beslenmeleri, aldıkları insülin tedavisi, kan şekeri ölçümü ile ilgili diğer çocukların alay etmesi, diyabetli bir çocuk için kabul edilemezdir. Bu nedenle daha büyük çocuklar hastalıklarını kendilerine daha yakın gördükleri arkadaşlarına söylemektedir veya hiçbir arkadaşına söylememeyi tercih etmektedir. Okul tarafından sunulan öğle yemekleri özensiz olabilmektedir. Dışarıda arkadaşları ile bir kafe veya restauranta gittiğinde uygun/sağlıklı besin bulmakta zorluk çekebilmektedir. Çocuklar büyüdükçe beslenme tedavisini uygulamada daha fazla zorluk yaşamaktadır (21).

\section{Tıbbi Beslenme Tedavisine Uyum Nasıl Ölçülür?}

Diyabetin tedavisi çok yönlü ve zorlayıcıdır, yaşam boyu sürmektedir. Hasta ve ailelerinin beslenme tedavisine uyum kapasiteleri ve istekleri çeşitlilik göstermektedir $(3,6)$. Tedaviye uyumun ölçülmesi 
sadece ilaç tedavisi alan hastalarda (hipertansiyon gibi) daha kolay iken, tedavide birden fazla bileşenin olduğu diyabet gibi hastalıklarda daha karmaşıktır. Diyabette, sorunun karmaşıklığı, uyumun ölçümünde altın standart yöntemin geliştirilmesini engellemektedir. Tedaviye uyumun ölçülmesinde doğrudan veya dolaylı yöntemler kullanılabilir. Vücut sıvılarında (idrar veya kan) ilişkili metabolitlere bakılması uyumu ölçen doğrudan yöntemler iken, besin tüketim günlüklerinin ve vücut ağırlık kaybının değerlendirilmesi, hastalıkla ilişkili alınması gereken ilaçların tabletlerinin sayılması, eczane veri tabanından alınan ürünlerin/ilaçların izlenmesi dolaylı yöntemler arasında sayılabilir (5). Diyabette beslenme tedavisine uyumu ölçen tek parametre bulunmamaktadır. Kullanılacak yöntemin kullanımının basit, ucuz, geçerli (valide) olması ve uyumun derecesi hakkında net bir kanıt sunması gerekmektedir (22).

Beslenmetedavisineuyumunundeğerlendirilmesinde, laboratuvar ölçümü olarak hastaların HbA1c, açlık ve tokluk kan glukoz değerleri, kan lipidleri ve kan basıncı değerleri, laboratuvar dışı kantitatif yöntem olarak hastaların, evde kan glukoz izlem sıklıkları (gün içerisinde ölçülmesi gereken ve unutulan kan glukoz değerleri), poliklinik muayenelerine katılma sıklığı, besin tüketim kayıtları, insülin reçete edilme kayıtları, kalitatif olarak da anket formları veya hasta ve ailesinin kendilerinin puanlayarak doldurduğu anketler veya testler kullanılabilir (5). Ayrıca video çekimi yoluyla hasta ve ailesinin beslenmeye yönelik davranışları da gözlemlenebilir. Ancak bu yöntemde yapay bir ortam oluşturulduğu için, gözlenen davranışlar doğal olmayabilir (23). Sağlık çalışanlarının önerilerine uyumun hasta veya ailesine sorularak doldurulduğu anketler, genellikle uyumu olduğundan daha fazla veya daha az olarak tahmin etme eğilimindedir (5).

Birleşik Devletler Sağlık ve Beslenme Araştırması'nda diyabet tanısı olan, gebe olmayan $\geq 20$ yaş bireylerin 2007-2010 yılları arasındaki kayıtları incelendiğinde, HbA1c <\%7, kan basincl 130/80 mmHg ve LDL kolesterol düzeyi $<100 \mathrm{mg} / \mathrm{dL}$ olan hastaların oranı (tedavide 3 hedefi de yakalayanların oranı) \%19 olarak bulunmuştur (24).

Ülkemizde 12 merkez ile 1032 tip 1 diyabetlinin değerlendirildiği bir çalışmada ise, son bir yılda ölçülen HbA1c düzeyleri >\%7.5 (orta ve zayıf derecede metabolik kontrol) olan hastaların oranı \%68.4 olarak bulunmuştur. Hastaların son bir yllda \%4.9'u ciddi hipoglisemi (mental durumunun değişmesi, koopere olamaması, koma, glukagon veya i.v. glukoz tedavisi), \%5.2'si de ketoasidoz (kan glukozu >200 mg/dL, venöz $\mathrm{pH}<7.3$ veya bikarbonat $<15 \mathrm{mmol} / \mathrm{L}$, ketonemi ve ketonüri) yaşamıştır. Son bir yılda dislipidemi (total kolesterol $>200 \mathrm{mg} / \mathrm{dL}$ ve/veya LDL kolesterol $>100$ $\mathrm{mg} / \mathrm{dL}$ ve/veya HDK kolesterol $<42 \mathrm{mg} / \mathrm{dL}$ ) oranı $\% 17.5$ olarak saptanmıştır. Dislipidemi oranı püberteden sonra artmaktadır. Aynı çalışmada son bir yılda HbA1c düzeylerine göre hastaların poliklinik muayenelerine katılma oranları incelendiğinde ise, yılda 3 ve daha az poliklinik muayenesine katılanların oranı \%59.4 olarak bulunmuştur ve hastaların her poliklinik ziyaretinde diyetisyen tarafindan değerlendirilip değerlendirilmediği belirtilmemiştir (25).

Diyabette uyumun ölçütlerinin araştırılması amacıyla hazırlanan sistematik bir derlemede, tıbbi beslenme tedavisine ilişkin olarak parantez içerisinde belirtilen hedeflerden (i.enerjinin büyük kısmının karbonhidratlardan sağlanması, ii.enerji alımının $<\% 30$ yağdan sağlanması, iii. doymuş yağ alımının $<\% 10$ olması, iv. proteinden gelen enerjinin \%1020 olması ve v.kolesterol alımının 200-250 mg/gün olması) en az dördünün yakalanmasının ve ayrıca hastaların poliklinik vizitlerinin \%75'inden fazlasına katılmasının, hastanın tıbbi beslenme tedavisine uyumunun iyi olması şeklinde yorumlanabileceği belirtilmiştir (22).

\section{Tıbbi Beslenme Tedavisine Uyumu Artırmak Neler}

\section{Yapılmalıdır?}

Diyabetli bireylerin beslenme tedavisine uyumlarını geliştirmek için bazı pratik yaklaşımlar ve stratejiler geliştirilmiştir. $\mathrm{Bu}$ yaklaşımlardan hiçbiri evrensel olarak etkili değildir ve beslenme tedavisine uyum 
sorunlarını düzeltmek için bireyselleştirilmiş yaklaşımların kullanılması gerekmektedir (6):

Beslenme Eğitimi: Hastalığın iyi bilinmesi, hastalık tedavisine uyumu daha fazla arttırmamakla birlikte, hasta ve ailesinin beslenme konusunda eğitim alması, beslenme tedavisine uyumun artmasina yardımcl olacaktır. Hasta ve ailelerinin diyabetin etkilerini, beslenme tedavisinin yararlarını ve uyumsuzluk sonucunda ortaya çıkabilecek sorunları anlamaları gerekmektedir. Eğitim, bireysel veya grup olarak, yazılı ve görsel materyalden yararlanılarak yapılabilir. Eğitim tartışma ve açıklamaları içermelidir, sorular yanıtlanmalıdır (6). Eğitim materyali geliştirilirken, materyali kullanacak hastaların da bu sürece dahil olması gerekmektedir. Böylece hastaların kendi istekleri ve eksiklikleri doğrultusunda geliştirilen eğitim materyali daha etkili olacak, hastaların beslenme tedavisine uyumları da artmış olacaktır (26). Diyabetli bireylerde kullanılan eğitim yöntemleri, yüz yüze eğitim/bireysel danışmanlık, basılı materyal/ broşürler, destek/aile grupları, besin hazırlama çalıştayları, eğitim günleri, seminerler, grup klinikleri, bilgisayar programları/oyunları, ev ziyaretleri, odak grupları, hafta sonu poliklinikleri, sosyal aktiviteler ve kamplardır $(21,27)$.

Farklı kronik hasta gruplarında yapılan çalışmalarda iki farklı eğitim materyalinin (kişisel ajanda ve pişirme DVD/tarif kitabı) hastalıkla ilişkili biyokimyasal parametrelerle ilişkisi araştırılmış, kişisel ajandanın hastalıkla ilişkili biyokimyasal kontrolü geliştirmediği, DVD/tarif kitabının ise hasta ve ailelerinin \%25'i ve daha fazlası tarafindan kullanılmadan bir kenara konduğu gösterilmiştir (6). Avrupa, Kuzey Amerika, Kanada, Meksika, Arjantin, Türkiye, Avusturalya ve Tunus'ta yaşayan 169 sağlık çalışanı ile 719 hasta ve ailesi ile yapılan bir çalışmada, aileler en etkili eğitim yönteminin bireysel danışmanlık olduğu, en az etkili yöntemin ise basılı materyal/broşür olduğu belirtilmiştir (27).

Odak (focus) grup çalışmaları küçük gruplar ile kapalı toplantılar halinde ve katılımcı kişilerin belirli bir konu hakkında görüşlerinin saptanması amacı ile yapılan niteliksel çalışmalardır. Diyabetli adölesan ve erişkinlerde de odak grup çalışmalarının yapılması, hastalarm beslenme tedavisine uyumsuzluk nedenlerinin daha iyi anlaşılmasına ve çözümüne yardımcı olacaktır. Adölesanlarda yapılan bir odak grup çalışmasında, adölesanların beslenme tedavisine uyumlarını arttırmak ve tedavinin sağlık yararlarını hatırlatmak için, tedavi edilmemiş hastalarla yapılan görüşmelerin aralıklı olarak bu hastalara izletilmesinin yararlı olacağı veya okulun başladığı ilk gün öğretmen ve öğrencilerin hastalık hakkında bilgi edinmeleri yoluyla, adölesanların tekrarlayan sorulara yanıt verme zorunluluğundan kurtulacakları belirtilmiştir (20).

Akran koçluğu aynı yaşlarda, benzer hastalığı sahip olan, benzer sorunları paylaşan çocukların birbirleriyle, uyuşmazlıkların çözümüne yardımcı oldukları bir süreçtir ve birçok kronik hastalıkta rutin tedavi planının bir parçası olarak uygulanmaktadır. Koç yerine mentor, danışman veya akıl hocası terimleri de kullanılmaktadır. Akran koçları üç tür destek sağlamaktadır: i) duygusal, ii) kendi kendine bakımı destekleyici ve iii) pratik, bilgi amaçlı (kendi canlı deneyimlerimi paylaşma). Koçluk yöntemiyle daha önce eğitim almış bir hasta veya hasta ebeveyni aracılığıyla hasta ve ailesine rutin tedavi hizmetinde yer almayan bir sağlık desteği verilmiş olacaktır. Koçluk yapacak hasta ve ebeveyninin hastalık eğitimi konsunda yeterliliğinin sağlık personeli tarafından değerlendirilmesi gerekmektedir (28).

Hasta eğitiminde kullanılacak diğer bir yöntem diyabet kamplarıdır. Diyabet kampları, tıbbi olarak güvenli bir ortamda geleneksel kamp deneyimini yaşatarak, hastaların hastalıkla ilgili bilgilerini geliştirmek, tedaviye uyumlarını arttırmak, diğer diyabetli bireyler ile arkadaşlık kurmasını ve hastalıkla ilgili deneyimlerini paylaşmalarını sağlamak, değişik fiziksel ve sosyal aktiviteler ile kendi yeteneklerine olan güvenlerini arttırmak, hastaların ailelerden ayrı bir ortamda hastalıkla başa çıkabileceklerini öğretmek, depresyon ve kaygıları azaltarak kronik bu hastalığa bağlı psikolojik sorunların çözüm yollarına yardımcı olmak, hastalıkta oluşabilecek 
komplikasyonları konusunda bilgi vermektir. Hasta kampları bu amaçların dışında tedavi ekibinde yer alan sağlık personelinin de eğitimi ve hastayı ve yaşadığı sıkıntıları daha yakından tanıması için de çok önemli bir firsattır. Ülkemizde de diyabet kampları diyabet eğitimi ve kendi kendine bakımı sağlamak amacıyla uzun yıllardır başarı ile uygulanmaktadır. Tip 1 diyabetli bireylerde yapılan bir çalışmada kamp öncesi ile karşılaştırıldığında, kamp sonrası 3. ve 6 . aylarda hastaların toplam günlük insülin dozlarında ve HbA1c düzeylerinde önemli azalmaların olduğu, ayrıca kamp sonrası 12 ay boyunca hastalarda ciddi hipoglisemi ve ketoasidoz gözlenmediği bulunmuştur (29).

Günümüzde birçok ülkede ev ziyaretleri, tıbbi beslenme tedavisi hizmetinin bir parçası olarak kullanılmaktadır. Ev ziyaretleri ile hasta/ailesine diyetisyen tarafindan kesintiye uğramadan zaman verilmesi sağlanır, aile üyelerinin tümü ile görüşülerek soruları yanıtlanır. Tüm aile bireylerine aynı anda tutarlı mesaj verilme şansı vardır. Hastalığın beslenme tedavisi ile ilgili tüm bilgiler adım adım aktarılabilir. Hasta/ailesinin evdeki uygulamaları gözlenip düzeltilebilir. Pratik uygulamalar gösterilebilir. Ancak ev ziyaretlerinin yapılabilmesi için hasta/ailelerinin tedavi merkezine belirli bir uzaklıkta yaşıyor olmaları gerekmektedir. Ayrıca ev ziyaretleri yapılabilmesi için gerekli bütçe tedavi merkezi tarafından sağlanmalıdır (kişisel gözlem-deneyim).

Uzaklığın kritik etmen olduğu birimlerde, sağlık çalışanları tarafından hastalığın önlenmesi, tanısı ve tedavisi için geçerli bilginin paylaşımı amacıyla bilgi ve iletişim teknolojileri kullanarak sağlık bakımının sağlanmasına “Teletıp”adı verilmektedir. Dört temel amacı vardır: (i) klinik destek sağlamak, (ii) sağlık çalışanı ile aynı bölgede yaşamayan hastaların coğrafik bariyeri ortadan kaldırmak, (iii) çeşitli türde bilgi ve iletişim teknolojileri kullanmak ve (iv) sağlık çıktısını geliştirmek. En fazla kullanıldığı alanlar, teleradyoloji, telepatoloji, teledermatoloji ve telepsikiyatridir (30). Hastanın tedaviye uyumunu geliştiren dijital sistemler, telefon görüşmeleri, cep telefonu aracılığıyla gönderilen kısa mesajlar, uygulamalar, internet aracılığıyla yapılan video görüşmeleri ve hastaların kullandıkları giyilebilir (sağlık bantları, akıllı saatler, kalp atımını izleyen) cihazlardır (31). Tip 1 diyabetli 74 hastanin rastgele olarak standart hastane muayenesi ve telekonsültasyon olarak iki gruba ayrıldığı ve bir yıl süresince (4. 8. ve 12. aylarda) izlendiği bir çalışmada, HbA1c düzeylerinin izlem süresince önemli düzeyde değişmediği ve gruplar arasında önemli bir farkın olmadığı bulunurken, telekonsültasyon alan grupta ciddi hipoglisemi episodlarında önemli azalma gösterilmiştir. Ayrıca telekonsültasyon alan grup tedaviden daha memnun olduklarını, ayrıca zaman ve para tasarrufu sağladıklarını belirtmişlerdir (31).

Teletıbbin Beslenme ve Diyetetik alanında kullanılması ise tıbbi beslenme tedavisi alacak hasta ile diyetisyenin yüzyüze görüşmesi yerine telefon veya internet aracılığıyla görüşmesi şeklinde yapılmaktadır. Hastaların birçoğu iş veya okul nedeniyle meşgul olmakta, bazı hastaların hareket kısıtlılıkları bulunmakta, hastanın izlendiği birim ile yaşadığı bölge arasında uzun mesafe olabilmekte ve sonuç olarak hasta/ailelerin tedavi merkezine ulaşması hem zaman kaybına neden olmakta, hem de maliyet açısından bir yük getirebilmektedir. $\mathrm{Bu}$ nedenle hasta/ailelerinin kendi ev ortamlarında diyetisyen ile görüşmeleri sağlanarak, daha sık görüşme imkanı olmakta ve bu hastaların beslenme tedavisine uyumu artmaktadır. Görüşmenin başarılı geçmesi ve hastaların tedaviye uyumlarının artması için bazı kuralların uygulanması gerekmektedir. Görüşmenin ofis vizitleri gibi olması sağlanmall, hem diyetisyenin hem de hastanın bulunduğu ortam sessiz ve kişiye özel olmalı, kulaklık kullanılması gerideki seslerin duyulmamasını ve karşılıklı anlaşılmanın daha iyi olmasını sağlayacaktır, görüşme esnasında hastanın mahremiyeti için mikrofon kullanılmamalıdır. Telefon kullanılıyorsa vücut dili, yüz ifadesi gibi gözlemler olmayacaktır, bu nedenle diyetisyenin aktif dinleme göstergelerini kullanması gerekmektedir. Ses tonu, tereddütler ve duraklamalar gibi sözel ipuçlarına dikkat edilmelidir. Görüşme saatlerinin unutulmaması için telefon veya e-posta aracılığıyla 
hatırlatma mesajları gönderilmelidir. Gönderilen bu mesajların kişinin özel telefonuna veya mailine gönderilmesi önemlidir. Teletıp konsültasyonu ile ilgili olarak lokal veya ulusal önerilere uyulmalıdır. Kullanılan yazılımın lisanslı olması ve güvenli olması önemlidir. Birçok ülkede teletıp sigorta kapsamında değildir. Hastalar bu hizmeti kendi ceplerinden satın almaktadır. Özellikle mesafenin tedaviyi engellediği hasta gruplarında teletıp uygulamasının geri ödeme kapsamında olması sağlanmalıdır (kişisel yorum).

Diyabetli bireylerin tedavisinde "kendi kendine bakım” yönteminin kullanılması ile ilgili yapılan çalışmalar giderek artmaktadır. Diyabet, günlük hayatta karar vermeyi ve karmaşı bakım aktivitelerinin yapılmasını gerektiren, kronik bir hastalıktır. Diyabetin kendi kendine izlemi ve bakımı için verilen eğitim programlarında, hastaların diyabetin bakımı için gerekli bilgi, beceri ve yeterlilikleri geliştirilmeye çalışılmaktadır. Ülkemizde ulusal düzeyde yapılandırılmış eğitim programları olmamakla birlikte, tedavi merkezlerinin oluşturduğu eğitim programları yaygın şekilde hasta eğitiminde kullanılmaktadır. Amerikan Diyabet Birliği, “Diyabette Kendi Kendine İzlem ve Bakım” eğitiminin tüm diyabetlilere verilmesini önermektedir. Bu eğitim programı ile hastaneye başvuruların, sağlık bakımı için gerekli harcamaların ve komplikasyonların ortaya çıkmasının azaldığı bilinmektedir (32). Diyetisyenlerin de tüm diyabetli bireylere ilaç/insülin, besin tüketimi, egzersiz ve kan glukoz kayıtlarının tutulmasını ve sonuçların yorumlanarak tedavide hastanın etkin rol alma becerisini öğretmesi gerekmektedir.

\section{Beslenme Tedavisiyle İlgili Yeni Yaklaşımların}

Geliştirilmesi: Basit bir beslenme tedavisine uyum, karmaşık bir beslenme tedavisine uyumdan daha kolaydır. Diyabette beslenme tedavisinin hasta/aile tarafından anlaşılabilirliğini gösteren çalışma sayısı sınırlıdır (6). Beslenme tedavisi yönteminin karmaşık olması, çocuğun bakımından sorumlu olan kişinin bilgisinin de sınırlı olmasına neden olacaktır. Yaş arttıkça çocukların da beslenme tedavisi hakkındaki bilgi düzeyleri artmaktadır. Çocuğun beslenme tedavisine uyumunu sağlama konusunda çok katı olmak ve çok esnek olmak arasında hassas bir denge vardır. Beslenme tedavisinde çok sinırlı uygulama yapılması, kan glukoz kontrolünü bozabilmektedir. Tüm bu nedenlerle diyabetli bireylerde beslenme tedavisine uyumu arttırmak için, ulusal düzeyde değişim listelerinin oluşturulması, hastaların besinlerdeki karbonhidrat değerini tahmin etmesini/ hesaplamasını kolaylaştırmak için fotoğraflı atlasların hazırlanması, diyetisyenlerin eğitimi için çalıştay ve uygulamaların yapılması, hastaların istek ve tercihleri gözönüne alınarak yeni yaklaşımlar geliştirilmesi önemlidir.

Hasta ve Ailesinin Tedaviye Dahil Edilmesi: Çocuk hastalarda beslenme tedavisinin başarısı ebeveynlerin becerileri, disiplinleri, motivasyon ve organizasyon yeteneklerine ve devaml uygulama ve denetleme gerektiren tedavi ile başa çıkma durumlarına bağlıdır. Aile ortamı, beslenme tedavisine uyumu destekleme veya uyumdan uzaklaştırma potansiyeline sahiptir. Ailedeki uyum sorunlarl, tek ebeveynli aileler ve boşanmalar beslenme tedavisine uyumu olumsuz yönde etkilemektedir. Diyabetli bir çocukla birlikte sağlıklı bir çocuğun aynı evde yaşaması aile için zorlayıcıdır. Tedavide aile desteği önemlidir, ancak bu desteğin aşırı müdahale şeklinde olmaması gerekir. Sağlık çalışanının tüm bu etmenleri değerlendirmesi gerekir (3). Diğer kronik hastalıklarda yapılan çalışmalarda, hasta tedavisi konusunda diğer aile üyelerinin bilgilendirilmesinin tedaviye uyumu arttırdığı gösterilmiştir. Büyükanne/dedeler ve diğer akrabalar, sağlıklıbesin seçimi/alışverişi, hazırlanması ve pişirilmesi konularında yardımcı olabilirler. Diğer aile üyelerinin hastayı tedavi konusunda destekleme konusundaki istekleri ve becerileri tartışılmalı ve tanımlanmalıdır. Hastalığın beslenme tedavisi ile ilgili negatif yaklaşıma sahip olan veya hastalığın doğasını anlamayan aile üyeleri, tedaviye uyum konusunda bariyer oluşturmaktadır (6).

Kendine Güven ve Yeterliliğin Geliştirilmesi: Çocukların büyüdükçe kendi beslenme tedavilerine ilişkin daha fazla sorumlulukalmalarıbeklenmektedir. Tedavinin gerektirdiği sorumluluklar aileden hastanın kendisine geçerken ailelerin daha geri plana çekilmesi 
ve hastaların pratik ve teorik anlamda hastalık ve beslenme tedavisi konusunda daha fazla bilgi sahibi olmaları gerekmektedir. Bunun dışında, hastalığın nöropsikolojik etkileri nedeniyle hastalar tedavilerini kontrol etmede çeşitli zorluklar yaşayabilirler. Metabolik kontrolü kötü olan hastalarda, planlama ve organizasyon becerilerinde azalma ve dikkat eksikliği gibi bilişsel işlevlerde görülen zayıflık, hastaların tedavisinin gerektirdiği günlük organizasyon ve plan yapma becerilerini etkileyebilir. Bunun yanı sira hastalıkta görülen ruhsal değişiklikler hastaların beslenme tedavisine uyum motivasyonlarinı azaltabilir (3).

Hastalara erken yaşlardan itibaren programlanmış öğrenme, teorik bilginin ve pratik becerilerin kazandırılması yoluyla kendi tedavilerinin yönetimi öğretilerek, ailenin tedavi sorumluluğunu çocuğuna devretmesi ve çocuğun kontrol duygusunu kazanması desteklenecek, böylece ileriki yaşlarda beslenme tedavisine uyum sağlanmış olacaktır (6).

Davranış Tedavisi: Davranış tedavisi ipuçları, hatırlatıcıları ve ödülü kapsamaktadır. Bu yaklaşımlar beslenme tedavisine uyumla ilişkili davranışların pekişmesine yardımcı olacaktır. İpuçları uyumsuzluğun düzeltilmesine yardımcıdır. Diyabetli hastalarda kan glukoz izlemi yapılması ile ilgili hatırlatıcı iletiler kullanıldığında (otomatik telefon çağrısı veya mektup), özellikle bu iletilerin sayısı bir yerine iki olduğunda uyumun arttığı gösterilmiştir. Mekanik veya otomatik hatırlatıcı notlar, otomatik veya kişisel telefon çağrıları veya SMS mesajları kullanıldığında, hastaların veya ailelerin evde zamanında kan glukoz ölçümü yapmaları sağlanmış olacaktır. Kan glukoz ölçümleri veya besin tüketim kayıtları düzenli yapıldığında ve hastaların hedef HbA1c düzeylerine ulaşıldığında, ödül veya övgü yöntemleri kullanılabilir (6).

Hasta/Ailesi ve Sağlık Çalışanı Arasındaki İletişimin Düzenlenmesi: Hasta/ailesi ve sağlık çalışanı arasında güçlü, açık ve dürüst bir ilişkinin kurulması önemlidir. Beslenme tedavisine uyma ve tedavinin yararlarına karşı gelişen bariyerler, hasta ve ailesinin görüşleri alınarak tartışılmalıdır. Tedavi hedeflerine birlikte karar verilmelidir (6). Özellikle adölesan dönemindeki hastalar için ebeveynle konuşmak yerine, hastanın kendisi ile samimi ve dürüst bir şekilde iletişim kurulması, adölesanın ciddi bir şekilde önemsendiği, dinlendiği ve düşünüldüğü duygusunun kurulmasına yardımcı olunacaktır. Güven duygusunun kurulması için, beslenme tedavisinin detaylarına yoğunlaşmak yerine, adölesanın endişeleri üzerine yoğunlaşılmalıdır (33).

Diyetisyene Ulaşılabilirliğin Arttırılması: Diyabetin tüm türlerinde hasta, tedavinin en önemli basamağını verecek olan diyetisyene yönlendirilmelidir. Ülkemizde gestasyonel diyabet bakım ve tedavisi veren 2007 yılında 436 hekim (188 aile hekimi, 155 intern, 91 kadın doğum uzmanı) ile yapılan bir çalışmada, hekimlerin hastalarının \%51.6'sını diyetisyene yönlendirmedikleri bulunmuştur. Hastalarını diyetisyene yönlendirmeyen hekimlerin \%13.6’sı broşür ile eğitim vermekte, \%25.6'sı ise beslenme eğitimini kendisi vermeyi tercih etmektedir. Hastaya hiç beslenme tedavisi önermeyenlerin oranı ise \%12.4'tür (34).

Avusturalya'da gestasyonel diyabetli 1000 kadında yapılan başka bir çalışmada ise, tedavide tıbbi beslenme tedavisi alan, kan glukoz izlemi yapılan ve gerekli olanlarda insülin tedavisi alan hastaların \%92'sinin diyetisyene yönlendirildiği saptanmış ve bu kadınlarda ciddi perinatal komplikayonların oranı \%1 olarak bulunmuş, rutin prenatal bakım alan ve sadece \%10'unun diyetisyene yönlendirildiği grupta ise ciddi perinatal komplikayonların oranı \%4 çıkmıştır (35).

Tedaviyi Uzman Bir Ekibin Yönetmesi: İdeal tedavi ve başarılı klinik sonuç için hasta mutlaka alanında uzman sağlık ekipleri tarafindan izlenmeli ve tedavi edilmelidir. Diyabetin beslenme tedavisinde en başarılı sonucu elde edebilmek için tedavi bireysel, klinik, sosyal, psikolojik, kültürel ve ekonomik gereksinmelere göre düzenlenmelidir ve ekip içerisindeyer alan diyetisyenlerin besin ve beslenmeye dair bilimsel bilgileri, pratik ve uygulanabilir hale dönüştürebilme yeterliliğine sahip olmaları 
gerekmektedir. Ülkemizde genellikle pediatri alanında çalışan diyetisyenler çocuk diyabetlilerin beslenme tedavisini üstlenirken, hem diyabet/endokrin merkezlerinde çalışan hem de birinci-ikinci ve üçüncü basamak sağlık merkezlerinde çalışan diyetisyenler diğer diyabetli hastalara hizmet vermektedir. Maalesef ülkemizde diyabette tıbbi beslenme tedavisinin uygulanmasına yönelik diyetisyenleri kapsayan bir uzmanlık alanı bulunmamaktadır. Ancak diyabet alanında çalışan diyetisyenlerin kendi aralarında iletişimlerini sağlamak, deneyim ve proje paylaşımlarına yardımcı olmak, gerekli bilgi kaynaklarını sağlamak, hem mezuniyet öncesi hem de mezuniyet sonrası eğitimi desteklemek amaciyla kurulmuş "Diyabet Diyetisyenliği Derneği” bu görevi üstlenmiştir. Diğer kronik hastalıklarda olduğu gibi diyabet alanında çalışan diyetisyenlerin uygulama ile ilgili bazı sorunlarının olduğu bilinmektedir. Diyetisyenler hastaların halihazırda elde etmiş olduğu haklar konusunda düzenli olarak bilgilendirmelidir. Araştırma yapmak, diyetisyenlerin bilgilerini arttırmak ve pratiklerini geliştirmek için desteklenmeleri gereklidir. Diyetisyenler diyabet konusunda araştırma projelerinin önemini bilseler de, bu alandaki araştırma projelerine katılma konusunda eksiklikleri bulunmaktadır. Projelere katılmama nedenleri arasında zaman eksikliği, işin yarı zamanlı olması, hasta sayısının az veya fazla olması, iş yükünün fazla olması ve bütçe yetersizliği sayılabilir. Aynı ülkede aynı alanda çalışan diyetisyenler arasında işbirliği oluşturularak, araştırma projelerinde yer almaları sağlanmalıdır. Diyabet alanında çalışan diyetisyenlerin eğitim kurslarına, profesyonel eğitim programlarına katılımlarının desteklenmesi gerekmektedir.

Tedavide Standart, Tutarlı ve Uyumlu Bilginin Kullanılması: Diyabet ile ilgili uzlaşı sonucunda oluşturulmuş ulusal veya uluslararası düzeyde birçok rehber bulunmaktadır. Uygulanacak rehberlerde uzlaşının olmaması ve hastalar için belirlenmiş farklı kan glukoz düzeyi hedeflerinin olması, hasta ve ailelerin farklı bireysel tercihler yapmalarına neden olabilir veya aynı sağlık ekibinin üyeleri hasta ve ailelerine farklı önerilerde bulunabilirler. Özellikle uyumun azaldığı adölesan ve erişkin döneminde var olan önerilerde çelişkili bilgiler bulunmaktadır. Hasta ve aileleri sosyal medya hesaplarından, çeşitli internet sitelerinden ve diğer bilgi kaynaklarından diyabet hastalığı ve tedavisi konusunda denetlenmemiş çok sayıda miktarda bilgiye kolaylıkla ulaşabilirler. Aynı birimde çalışan farklı meslek gruplarına mensup sağlık çalışanları bazen hastalara çelişkili bilgiler verebilmektedir. $\mathrm{Bu}$ nedenle hasta ve ailelerinin ulaştıkları bilgi kaynakları denetlenmeli, tedavi ile ilgili standart, tutarlı ve uyumlu hedefler içeren ulusal veya uluslararası rehberler geliştirilmeli, zaman içerisinde bu rehberler güncellenmeli, ekip üyelerinin hasta karşısında aynı dili konuşması sağlanmalıdır. Rehberler sadece ne yapılması gerektiği üzerine değil, nasıl yapılabileceğine ilişkin bilgileri içermeli, tedavi standartlarının arttırılması yolu ile tedaviye uyum da arttırılmalıdır.

\section{Kültürel ve Dini Özelliklerin Gözönünde} Bulundurulması: Geniş aile yapısı, yoksulluk, sinırlı pişirme olanakları, dil, konuşma, anlama becerisi ve okur yazarlık durumu gibi etmenler beslenme tedavisine uyumu etkilemektedir. Bazı popülasyonlarda besin sosyal olarak çok önemlidir ve eve gelen her misafire sunulmak üzere özel yiyecekler hazırlanır. Kültürel nedenlerden dolayı çocuğun bakımından primer sorumlu annelerin kendilerine eşlik eden biri olmadan eğitim etkinliklerine katılmalarına izin verilmeyebilir. Beslenme tedavisi ile ilgili uygulamalar ve bilgilere hakim olan kişi anne olmasına rağmen, klinikte sağlık uzmanlarıyla çoğunlukla babalar iletişime geçebilirler. Bazı aileler durumu kabullenmeme veya “Tanrı’nın isteği” düşüncesi ile dini inançlara uygun olmadiğı gerekçesiyle müdahale gerektiren bir tedavinin uygulanmasını istemeyebilirler. Aynı ailede birden fazla hasta çocuk olabilir. Bu ailelerle iletişim için konuya hakim ve ailenin de güvenini kazanmış profesyonel bir tercüman bulundurulmalı, sağlıklı besin hazırlama ve pişirme için besin hazırlama 
seminerleri/çalıştayları düzenlenmeli, bu çalışmalar dini/kültürel görüşlere uygun planlanmalıdır. Ayrıca bu hastaların eğitimine diğer aile bireyleri de (büyükanneler, büyükbabalar ve birlikte yaşanıyorsa diğer bireyler) dahil edilmelidir. Ev ziyaretleri yapılarak ailenin evdeki yaşam koşulları da değerlendirilebilinir (3).

Tedaviye Sosyal Servisin Dahil Edilmesi: Beslenme tedavisine uyumsuzluk kasitlı veya farkında olmadan gerçekleşebilir. Beslenme tedavisine kasıtlı bir şekilde uymayı reddeden hastalar, bunu bilinçli olarak yapmaktadır. Beslenme tedavisine/tedaviye uyumu bilinçli olarak reddeden ebeveynlerin çocukları "Sosyal Servis”e veya “Çocuk Koruma Servis”ine transfer edilebilirler ve bu çocuklar geçici veya kalıcı olarak bakıcı ailelerin gözetimine verilebilirler. Beslenme tedavisinin düzenli ve kasıtlı bir şekilde ihlal edilmesinin yanısıra alkol ve uyuşturucu madde bağımlılığı veya ciddi mental hastalığı olan ailelerin çocukları için de bu seçenek düşünülebilir (36). Bu seçenek ile çocuğun kan glukoz kontrolü sağlansa da, her zaman beklenen etkiyi yarattığ söylenemez. Özellikle kaygı ve yerleştirme sürecinin neden olduğu psikolojik ve duygusal travma hastanın beslenme tedavisinin kontrolünden daha önemli hale gelmektedir. Çocuk Koruma Servisi'nin yaklaşımları geçicidir ve beslenme tedavisine uyum uzun dönemde sağlık çalışanı ve aile arasındaki etkileşim geliştiğinde gerçekleşecektir (37).

\section{SONUÇ VE ÖNERILER}

Sonuç olarak beslenme tedavisine uyumu sağlamak için Dünya Sağlık Örgütü’nün 2003 yılında kronik hastalıklarda tedaviye uyumla ilgili yayınladığı raporda belirtiği gibi hastalar desteklemeli, suçlanmamalı, sağlık çalışanları da uyumu arttırma konusunda eğitilmelidir (2). Uluslararası tıbbi pediatri alanında etiğin temel prensibi olan "Çocuğun Üstün Yararı” yaklaşımına göre çocuk ailenin ayrılmaz bir parçasıdır ve hasta çocuğun ve ailenin eğitim, kültür ve sosyo-ekonomik durumuna göre aile merkezli bir beslenme tedavi planı uygulanmalıdır.
Çıkar çatışması - Conflict of interest: Yazarlar çıkar çatışması olmadığını beyan ederler. - The authors declare that they have no conflict of interest.

\section{KAYNAKLAR}

1. DiMatteo MR. Variations in patients' adherence to medical recommendations: a quantitative review of 50 years of research. Med Care. 2004;42(3):200-9.

2. WHO. Adherence to Long Term Therapies: Evidence for Action, Geneva, 2003.

3. MacDonald A, van Rijn M, Feillet F, Lund AM, Bernstein $\mathrm{L}$, Bosch AM, et al. Adherence issues in inherited metabolic disorders treated by low natural protein diets. Ann Nutr Metab 2012;61(4):289-95.

4. García MI, Araya G, Coo S, Waisbren SE, de la Parra A. Treatment adherence during childhood in individuals with phenylketonuria: Early signs of treatment discontinuation. Mol Genet Metab Rep. 2017;11:54-8.

5. Vermeire E, Hearnshaw H, Van Royen P, Denekens J. Patient adherence to treatment: three decades of research. A comprehensive review. J Clin Pharm Ther. 2001;26(5):331-42.

6. MacDonald A, Gokmen-Ozel H, van Rijn M, Burgard P. The reality of dietary compliance in the management of phenylketonuria. J Inherit Metab Dis. 2010;33(6):665-70.

7. Phillips LS, Branch WT, Cook CB, Doyle JP, El-Kebbi IM, Gallina DL, et al. Clinical inertia. Ann Intern Med. 2001;135(9):825-34.

8. Kaya ŞD, Yağcı M. Sağlık çalışanlarının atalet durumlarının hasta güvenliği ile ilişkisi. IJSSE 2015;1(2):453-62.

9. O’Connor PJ, Sperl-Hillen JAM, Johnson PE, Rush WA, Biltz G. Clinical inertia and outpatient medical errors. Adv Pediatr Safety. 2005;2:293-308

10. Parildar H, Cigerli O, Guvener Demirag N. Depression, coping strategies, glycemic control and patient compliance in type 2 diabetic patients in an endocrine outpatient clinic. Pak J Med Sci. 2015;31(1):19-24.

11. Sharman R, Mulgrew K, Katsikitis M. Qualitative analysis of factors affecting adherence to the phenylketonuria diet in adolescents. Clin Nurse Spec. 2013;27(4):205-10.

12. McCrimmon RJ, Ryan CM, Frier BM. Diabetes and cognitive dysfunction. Lancet. 2012;379(9833):2291-9. doi: 10.1016/S0140-6736(12)60360-2.

13. Martin LR, Williams SL, Haskard KB, DiMatteo MR. The challenge of patient adherence. Ther Clin Risk Manag 2005;1(3):189-99.

14. Cypress M. Health literacy and numeracy in diabetes nutrition therapy and self-management education. 
Franz MJ, Evert AB, editors. ADA Guide to Nutrition Therapy for Diabetes, 2nd Ed. Virginia: American Diabetes Association; 2012. 441 p.

15. Burgard P. Family conditions and dietary control in IEMs. J Inherit Metab Dis. 2007;30(5):629.

16. Olsson GM, Montgomery SM, Alm J. Family conditions and dietary control in phenylketonuria. J Inherit Metab Dis. 2007;30(5):708-715.

17. Alaei M, Asadzadeh-Totonchi G, Gachkar L, Farivar S. Family social status and dietary adherence of patients with phenylketonuria. Iran J Pediatr. 2011;21(3):379_ 384.

18. Medford E, Hare DJ, Carpenter K, Rust S, Jones S, Wittkowski A. Treatment adherence and psychological wellbeing in maternal carers of children with phenylketonuria. JIMD Rep. 2017;37:107-114.

19. Miller KM, Foster NC, Beck RW, Bergenstal RM, DuBose SN, DiMeglio LA, et al. Current state of type 1 diabetes treatment in the U.S.: updated data from the T1D Exchange clinic registry. Diabetes Care. 2015;38:971-8.

20. Sharman R, Mulgrew K, Katsikitis M. Qualitative analysis of factors affecting adherence to the phenylketonuria diet in adolescents. Clin Nurse Spec. 2013;27(4):205-210.

21. MacDonald A. Diet and compliance in phenylketonuria. Eur J Pediatr. 2000;159 Suppl 2:S136-141.

22. Hearnshaw H, Lindenmeyer A. What do we mean by adherence to treatment and advice for living with diabetes? A review of the literature on definitions and measurements. Diabet Med. 2005;23:720-8.

23. Ten Hoedt AE, Hollak CE, Boelen CC, van der Herbergvan de Wetering NA, Ter Horst NM, Jonkers CF, et al. "MY PKU": increasing self-management in patients with phenylketonuria. A randomized controlled trial. Orphanet J Rare Dis. 201127;6:48.

24. Casagrande SS, Fradkin JE, Saydah SH, Rust KF, Cowie CC. The prevalence of meeting A1C, blood pressure, and LDL goals among people with diabetes, 1988-2010. Diabetes Care. 2013;36:227-9.

25. Gökşen Şimsek D, Aycan Z, Ozen S, Cetinkaya S, Kara C, Abalı S, et al. Diabetes care, glycemic control, complications, and concomitant autoimmune diseases in children with type 1 diabetes in Turkey: A multicenter study. J Clin Res Pediatr Endocrinol. 2013;5(1):20-6.

26. Durham-Shearer SJ, Judd PA, Whelan K, Thomas JE. Knowledge, compliance and serum phenylalanine concentrations in adolescents and adults with phenylketonuria and the effect of a patient-focused educational resource. J Hum Nutr. Diet 2008;21(5):47485.

27. Bernstein LE, Helm JR, Rocha JC, Almeida MF, Feillet F, Link RM, et al. Nutrition education tools used in phenylketonuria: clinician, parent and patient perspectives from three international surveys. J Hum Nutr Diet. 2014;27Suppl2:4-11.

28. Tully C, Shneider C, Monaghan M, Hilliard ME, Streisand R. Peer coaching interventions for parents of children with type 1 diabetes. Curr Diab Rep. 2017;17:39-49.

29. Karagüzel G, Bircan I, Erişir S, Bundak R. Metabolic control and educational status in children with type 1 diabetes: effects of a summer camp and intensive insulin treatment. Acta Diabetol. 2005;42:156-61.

30. WHO. Telemedicine. Global Observatory for eHealth series - Volume 2. Geneva, 2010.

31. Bertuzzi F, Stefani I, Rivolta B, Pintaudi B, Meneghini E, Luzi L, et al. Teleconsultation in type 1 diabetes mellitus (TELEDIABE). Acta Diabetol. 2018;55(2):185-92.

32. Powers MA, Bardsley J, Cypress M, Duker P, Funnell MM, Fischl AH, et al. Diabetes self-management education and support in type 2 diabetes: A joint position statement of the American Diabetes Association, the American Association of Diabetes Educators, and the Academy of Nutrition and Dietetics. Diabetes Care. 2015;38:1372-82.

33. Gentile JK, Ten Hoedt AE, Bosch AM. Psychosocial aspects of PKU: hidden disabilities-a review. Mol Genet Metab. 2010;99Suppl 1:S64-67.

34. Akinci B, Tosun P, Bekci E, Yener S, Demir T, Yesil S. Management of gestational diabetes by physicians in Turkey. Prim Care Diabetes 2010;4:173-80.

35. Reader DM. Nutrition therapy for pregnancy, lactation, and diabetes. franz MJ, Evert AB, editors. ADA Guide to Nutrition Therapy for Diabetes, 2nd Ed. Virginia: American Diabetes Association; 2012. 181 p.

36. van Rijn M, Ahring K, Bélanger-Quintana A, Dokoupil K, Ozel HG, Lammardo AMet al. When should social service referral be considered in phenylketonuria? Mol Genet Metab Rep. 2015;2:85-88.

37. Stockler S, Moeslinger D, Herle M, Wimmer B, Ipsiroglu OS. Cultural aspects in the management of inborn errors of metabolism. J Inherit Metab Dis. 2012;35(6):11471152. 